\title{
The LOC Learning Model on Student Learning Achievement in Theme 7 of Sub-Themes 1 of The Science Content
}

\author{
${ }^{*}$ Lilis Pidianti ${ }^{1}$, Yopa Taufik Saleh ${ }^{2}$, Meiliana Nurfitriani ${ }^{3}$
}

1,2,3 Prodi Pendidikan Guru Sekolah Dasar, Universitas Muhamadiyah Tasikmalaya, Indonesia

\author{
A R T I C L E I N F O \\ Article history: \\ 1 Maret 2020 Received in \\ revised form \\ 30 Maret 2020 \\ Accepted 11 April 2020 \\ Available online 25 Agustus \\ 2020 \\ Kata Kunci: \\ Inside the outside circle \\ prestasi belajar \\ Keywords: \\ Inside outside circle, \\ learning achievement.
}

\begin{abstract}
A B S T R A K
Pembelajaran bersifat teacher centered, dalam proses pembelajaran guru hanya menggunakan model pembelajaran konvensional dengan metode ceramah sehingga siswa merasa jenuh dan bosan dalam mengikuti pembelajaran yang mengakibatkan prestasi belajar siswa menjadi rendah. Penelitian ini bertujuan untuk mengetahui pengaruh model pembelajaran IOC terhadap prestasi belajar siswa pada tema 7 subtema 1 muatan IPA di kelas IV SD. Jenis penelitian yang digunakan dalam penelitian ini adalah kuantitatif dengan menggunakan Quasi Experimental Design dengan bentuk desain nonequivalent control group design. Populasi yang digunakan pada penelitian ini adalah seluruh siswa kelas IV SD yang berjumlah 30 siswa. Sampel yang digunakan yaitu seluruh populasi (total sampling), untuk pengambilan sampel memakai cara simple random sampling. Untuk teknik pengumpulan data menggunakan test yaitu pretest dan posttest serta data dianalisis
\end{abstract} dengan menggunakan aplikasi SPSS 25. Dari hasil data yang telah dianalisis, diperoleh sig 0,003 < 0,05 yang berarti $\mathrm{H}_{0}$ ditolak. Model Pembelajaran Inside Outside Circle (IOC) memiliki pengaruh yang signifikan terhadap prestasi belajar siswa kelas IV SD pada tema 7 subtema 1 muatan IPA. Memperoleh thitung yaitu 3,306 dan ttabel yaitu 2,04841. Untuk thitung yang didapat berada pada wilayah yang positif atau 3,306 $>2,04841$ sehingga $\mathrm{H}_{a}$ diterima. Nilai rata-rata kelas eksperimen yaitu 82,33 dan kelas kontrol yaitu 70,33 (82,33 > 70,33). Maka model pembelajaran Inside Outside Circle (IOC) memiliki pengaruh positif terhadap prestasi belajar siswa kelas IV SD pada tema 7 subtema 1 muatan IPA.

\section{A B S T R A C T}

This research talks about research that uses the Inside-Outside Circle (IOC), the learning model. This study aimed to determine the effect of the IOC learning model on student achievement on the theme 7 sub-themes 1 of science content in grade IV SDN Kersagalih. The type of research used in this study was quantitative by using Quasi-Experimental Design with the design of nonequivalent control group design. This research was conducted at Kersagalih Elementary School. The population was all students in grade IV Kersagalih Elementary School, totaling 30 students. The sample used was the entire population (total sampling), the sampling was a simple random sampling method. For the data collection techniques used tests that were pretest and posttest and the data were analyzed using the SPSS 25 application. From the results of the analyzed data, it was found that sig $0.003<0.05$, which means that $\mathrm{HO}$ is rejected. The Inside-Outside Circle (IOC) Learning Model has a significant influence on the learning achievement of the fourth-grade students of SDN Kersagalih on the theme 7 subthemes 1 of science content. Obtaining a t-count is 3.306 and the t-table is 2.04841 . For t-count obtained in a positive region or 3.306> 2.04841 so that $\mathrm{Ha}$ is accepted. The average value of the experimental class is 82.33 and the control class is 70.33 (82.33> 70.33). So, the Inside-Outside Circle (IOC) learning model has a positive influence on the learning achievement of the fourth-grade students of Kersagalih Elementary School on the theme of 7 sub-themes 1 of science content.

Copyright (@) Universitas Pendidikan Ganesha. All rights reserved 


\section{Introduction}

Learning is a human activity that is very important in every type and level of education. The success or failure of achieving educational goals depends on the learning process, so a correct understanding of learning is needed. (Sudjana, 2010; Nidawati, 2013) (states that learning is a process characterized by a change in one's self, in the words the basic process of the development of human life. By learning, humans make individual qualitative changes so that their behavior develops. Learning is not just an experience, learning takes place actively and integratively with various forms of action to achieve a goal. Learning is also a change in behavior towards a change in good behavior, where these changes occur through practice or experience. Based on the understanding of learning above, it can be concluded that first, learning is the process of acquiring knowledge. Second, learning is a relatively lasting change in the ability to react as a result of strengthened training. (Sohimin, 2014) states that learning is a system that has a very dominant role in realizing the quality of education. So that in schools the role of teachers and students is very influential in realizing the quality of education, namely by carrying out the learning process in each subject. One of the subjects that must be studied in elementary school is Natural Sciences (IPA). Natural Science Education (IPA) based on the 2006 KTSP curriculum is one of the subjects taught in primary school education. Samatowa (Hendawati, Yuyu, 2018) argues that IPA discusses natural phenomena that are systematically arranged based on the results of experiments and observations made by humans. Science in its application is generally limited to natural phenomena, born and developed through scientific methods such as experimentation and observation. The knowledge gained in science learning is also very important because it can be applied directly to society. According to Srini M. Iskandar (Suadi \& Lipur, 2019) Some of the reasons for the importance of science subjects, namely, science is useful for the life or work of children in the future, part of the nation's culture, trains children to think critically, and has educational values that have the potential to form a child's personality as a whole.

Prihantro Laksmi (Fatimah \& Kartika, 2013) stated that science learning in Bloom's Taxonomy is expected to provide knowledge (cognitive), which is the main goal of learning. This type of cognitive science knowledge is a basic knowledge of principles and concepts that are useful in everyday life. Broad knowledge of facts that exist in nature to be able to understand and deepen further, and see the information and order (Arista, Shelly Afrilia, 2017). In addition, science learning is also expected to provide skills (psychomotor), scientific attitudes (affective), understanding, habits, and appreciation (Sariadi, 2014). (Apriani, 2016) states that the cognitive domain includes 1) knowledge (knowledge, memory), 2) comprehension (understanding, explaining, summarizing, examples), 3) application (applying), 4) analysis (describing, determining relationships), 5) synthesis (organizing, planning, forming new buildings), 6) evaluating (assessing). Science learning is said to be successful if all the main objectives of the predetermined learning can be achieved (Fatinah, 2017). To achieve effective learning goals in science, students are expected to be able to go directly with systematic stages through various logical stages, such as developing curiosity, a positive attitude, and leading to discoveries that are applied in everyday life (Ariyanto, 2016; Mulyasa, 2011). Science learning in elementary schools emphasizes providing direct experience to develop competencies to explore the natural surroundings scientifically. In line with this, Sudana (Utami \& Renda, 2019) state that every learning, including science learning, should be able to create learning situations that are interactive, inspiring, challenging, motivating, and fun. In the implementation of science learning, teachers play an important role in creating interactive learning conditions so that students feel happy when they are in learning to achieve optimal learning achievement.

According to Poerwadarminta (Purnamawanti, 2015), the achievement is the result that has been achieved, while learning is trying to gain intelligence or knowledge by memorizing. Learning achievement is a learning achievement that is achieved after going through the process of teaching and learning activities (Syafi'i, 2018). Learning achievement can be shown through the value given by a teacher from the number of subjects that have been studied by students. The achievement of learning achievement or student learning outcomes can be classified into several aspects such as; cognitive aspects, affective aspects, and psychomotor aspects. In other words, the three aspects of learning achievement, namely: those which include affective aspects, cognitive aspects, and psychomotor aspects would be more perfect if these three aspects were owned by each student. So that students are not only smart in subjects but also smart in applying them to everyday life. Learning achievement cannot stand alone but always relate to one another. In the process of achieving it, learning achievement is greatly influenced by various factors. One of the main factors that greatly influence the success of learning is the presence of a teacher. Given the existence of teachers in the process of teaching and learning activities is very influential, then the quality of teachers should be considered (Mulyasa, 2011; Syafi'i, 2018). In addition, high learning achievement is always desired by everyone, be it students, parents, and especially teachers. 
However, in reality, there are still schools that have low science learning achievement because they have not reached the predetermined standard of completeness. This can happen because the teaching methods used by teachers are still less varied so that learning is monotonous and will make students feel bored and less motivated to take part in learning. This of course will affect reducing student learning outcomes and achievement. The same thing was also found in the learning process in grade IV SDN Kersagalih. From the results of interviews conducted with grade IV teachers at SDN Kersagalih, according to Mrs. N. Oom Romdiah, S.Pd (as her homeroom teacher), the value of student learning outcomes in science subject semester 1 of the 2019/2020 school year got a score below the predetermined standard (under the KKM) there are 14 students, who get the KKM pass score of 10 students, and those who score above the KKM are 6 students. For the KKM science subject in grade IV, it is 67, while of 30 students the average UAS result score is only 65. In implementing learning activities, ideally, the teacher chooses an effective learning strategy or model according to the student's condition for creating interactive learning situations (students active in teaching and learning activities) so that the learning objectives can be conveyed. However, based on the results of observations, learning is teacher-centered, in the learning process the teacher only uses conventional learning models with the lecture method and students are asked to sit for hours to focus on listening to the material presented by the teacher. So that some students feel bored and find excuses to leave the classroom, including asking permission to go to the toilet, even though in the toilet he only washed his hands or wet his hair. From this it indicates that students feel bored, their motivation and enthusiasm for learning science also look very low. If this is allowed to happen, of course, students will be left behind in the lesson. In addition, if student motivation decreases while participating in learning, it will certainly have a bad effect on student achievement and learning outcomes.

In the learning process, the teacher should understand how to provide a stimulus so that students love learning science, actively participate in learning activities, are more motivated in participating in science learning so that students learn more meaningfully and better understand the material provided. states that teachers also need seriousness in using innovative learning techniques and learning media so that a good and successful teaching and learning process can be carried out. This of course will also have a big influence on improving student achievement. Various models in the learning process are also one of the supporters of successful learning. One learning model that can make students play an active role in learning is the Inside Outside Circle learning model. Inside Outside Circle is a learning model with a system of small circles and large circles that begins with the formation of large groups in the class consisting of inner circle groups and outer circle groups (Ningsih, 2017; Shoimin, 2014). This model trains students to be able to communicate well because in large groups students will convey information to small groups and vice versa. According to Lie in (Yuhastami, 2015), IOC learning techniques are learning techniques developed by Spencer Kagan to provide opportunities for students to share information at the same time. According to Huda in (Utami \& Renda, 2019), the advantage of the inside-outside circle learning model is that it has a clear structure and allows students to share information in a short and orderly manner. In addition, students work with fellow students in an atmosphere of cooperation and have many opportunities to process information and improve communication skills (Azmi, 2015). Active student involvement can be seen from the first stage to the final stage of learning.

Kagan (Wiwinda, 2016; Azmi Nurul, 2015) states that there are 5 main steps in implementing the IOC model, namely 1) half of all students in the class stand up to form a small circle facing outwards; 2) the other half of the students form a circle outside the first circle and face inward; 3) two pairs of students from small and large circles share information. This information exchange can be done by all couples at the same time; 4) students who are in the small circle stay in place, while students who are in the big circle move one / two steps clockwise, so that each student gets a new pair; 5) it is the students' turn in the big circle to share information. And so on. The use of the Inside Outside Circle learning model in learning is expected to be able to provide optimal achievement of student learning outcomes and be able to liven up the classroom atmosphere, and teaching and learning activities run effectively, able to make students active, help students to communicate skills, skilled in exploring individual or group abilities. (Azmi, 2015). Students will understand better if they receive information or material from friends conveyed by their peers because communicating with their peers will use the language they normally use. If students already understand the information provided by their peers, in other words, the learning objectives have been conveyed. So that it will affect learning achievement. Some of the advantages of this IOC model are 1) students can get different information at the same time, 2) more ideas that students can come up with when interacting directly with their friends, 3) able to influence student motivation and activeness, 4 ) help increase students' self-confidence, 5) help students assess their abilities, 6) invite students to be able to act so that students do not tend to be passive, and 7) trigger students to want to think and be skilled at speaking. 
This research is also in line with previous research that has been conducted by Saroyo, (Edi, 2016) on the Application of Inside-Outside Circle Learning Methods to Improve Student Learning Activities and Cognitive Learning Outcomes on Ecosystem Balance Material. He found that learning using an insideoutside circle learning model could improve student activity and cognitive learning outcomes. Another study was also conducted by (Barsihanor, 2016) who found that there was a positive effect of the application of the Inside Outside Circle learning model on student learning outcomes at MI Darul Mujahidin. In addition, research conducted by (Ningsih, 2017) on the Application of Inside-Outside Circle Learning Model to Students' Concept Understanding Ability. He found that the students' ability to understand mathematical concepts with the application of the Inside Outside Circle learning model was better than the ability to understand mathematical concepts of students who were subjected to conventional learning on cube and block material in class VIII Junior High School 3 Sungai Lala. Another research that is also in line is the research conducted by (Budiartini, 2018) on the effect of the Inside Outside Circle learning model assisted by portfolio assessment on science learning outcomes. He found that there were significant differences in science learning outcomes between groups of students who were taught with the Inside-Outside Circle (IOC) learning model assisted by portfolio assessment and groups of students who were taught using conventional learning models in class V students in the 2017/2018 school year at SD Gugus VI Buleleng District.

This shows that the Inside-Outside Circle learning model assisted by portfolio assessment has a positive effect on the science learning outcomes of fifth-grade students of SD Gugus VI, Buleleng District, 2017/2018 academic year. On the other hand, (Angganing, 2019) also researched the use of the Inside Outside Circle method to improve social studies learning outcomes. He found that the use of the Inside Outside Circle method in the learning cycle was able to improve student social studies learning outcomes. From the research that has been done, no one has researched the influence of Inside-Outside Circle on science learning achievement, so according to the researcher it is necessary to research with the title "The Effect of IOC Learning Models on Student Achievement in Theme 7 Sub-theme 1 Science Content in Class IV SDN Kersagalih ". The difference between the research that will be carried out with previous research is that in previous studies that have been carried out, it only found how the influence of the Inside Outside Circle learning model on social studies learning outcomes, science learning outcomes, and the concept of student understanding, no one has discussed the influence of the Inside Outside Circle learning model. While the research to be conducted is to find out how the influence of the Inside Outside Circle learning model has on the learning achievement of elementary school science learning.

\section{Methodology}

This research was conducted at SDN Kersagalih which is located at Kp. Cilendi, Kersagalih Village, Jatiwaras District, Tasikmalaya Regency during the second semester of the 2019/2020 school year theme 7 sub-themes 1 science content. This type of research was quantitative research using Quasi-Experimental Design. Quasi-Experimental Design is a development of true experimental design which has a control group of at least one variable even though it is in the form of matching, or matching/matching characteristics (Sukmadinata, 2016; Sugiyono, 2016). (Sugiyono, 2016) states that the population is a generalization area consisting of objects/subjects that have certain qualities and characteristics that are determined by researchers to be studied and then conclusions are drawn. The population used in this study were all grade IV students at SDN Kersagalih Jatiwaras District, Tasikmalaya Regency in the academic year 2019/2020 as many as one class with 30 students. While the sample used in this study were all students in class IV, amounting to 30 students. The sampling technique used in this research is total sampling by taking the sample using a random method or so-called simple random sampling. The method of determining student grouping was done by shaking the lottery, namely 15 students for the control class and 15 students for the experimental class.

This study used 2 types of variables, namely the independent variable and the dependent variable. The independent variable in this study was the Inside-Outside Circle learning model and the dependent variable is learning achievement (cognitive domain). While the data collection techniques that will be used in the research area) interviews, the purpose of conducting interviews is to provide initial information before conducting research. (Sugiyono, 2013) states that the interview technique is a data collection technique to gather information about the problem to be studied. The interview technique used by the researcher was an unstructured interview by asking about the number of students, the grades of the fourth-grade students in science subjects, the use of learning models in class, and the student's condition in learning, b) observation is an observation as an initial description of determining research. Nonparticipant observation is the observation used in this study because the researcher is not involved and 
only acts as an independent observer. c) the test is carried out to measure the extent to which the capabilities of the object to be used as research. (Sugiyono, 2013) states that the test is a series of questions or exercises used to measure the knowledge, intelligence, abilities, or talents possessed by individuals or groups. The test to be used is in the form of a learning achievement test at the pretest and posttest. d) documentation is a technique for obtaining data. The documentation in this study included school profiles, lesson plans, student scores, pretest scores, posttest scores, and photos when learning was carried out in the control group and the experimental group.

The data collection instrument used a test instrument, namely a written test in the form of multiple choices that previously made a grid as a reference in making questions. After making the data collection instrument, the validity of the instrument was carried out. (Sugiyono, 2016) states that a valid instrument means that the measuring instrument used to obtain data (measure) is valid. Valid means that the instrument can be used to measure what should be measured. The validity of the instruments to be used will be tested using the expert judgment method. The experts who were asked to assess or weigh the instruments in this study were a) Linguist Lecturers: Anggia Suci Pratiwi, M.Pd; b) Material Expert Lecturer: Moh. Fahmi Nugraha, M.Pd; c) Class IV teacher at SDN Kersagalih: N. Oom Romdiah, S.Pd. Then, validate the instrument using the help of the SPSS version 25 program with the Pearson product-moment by deciding if $>$ then the instrument is valid, but otherwise if $<$ then the instrument is invalid. The method of determining is with a significance of 0.05 and the number of questions is 20 , the result is 0.444 . Decide by comparing it can be seen in table 1 below:

Table 1. Recapitulation Validity Result

\begin{tabular}{cccc}
\hline Number of Item & $\mathbf{R}_{\text {count }}$ & $\mathbf{R}_{\text {table }}$ & Decision \\
\hline 1 & 0,802 & 0,444 & Valid \\
2 & 0,590 & 0,444 & Valid \\
3 & 0,506 & 0,444 & Valid \\
4 & 0,537 & 0,444 & Valid \\
5 & 0,700 & 0,444 & Valid \\
\hline
\end{tabular}

Based on table 1 above, it shows that the t-count results from questions 1 to 5 all show that the tcount is greater than the t-table. So that it can be concluded that the instruments used are valid and can be used for research. After performing the instrument validity, the instrument reliability test was then carried out. (Sugiyono, 2016) states that a reliable instrument is an instrument that, when used several times to measure the same object, will produce the same data. The instrument reliability category according to (Sugiyono, 2019) is described as in table 2 below:

Table 2. Reliability Coefficient Classification

\begin{tabular}{cc}
\hline Coefficient Interval & Relationship Level \\
\hline $0,00-0,119$ & Very low \\
$0,20-0,399$ & Low \\
$0,40-0,599$ & Moderate \\
$0,60-0,799$ & Strong \\
$0,80-1,000$ & Very strong \\
\hline
\end{tabular}

The technique of determining reliability uses SPSS version 25 by calculating the alpha coefficient. If the reliability results have a high level of relationship results, the instruments on these variables are reliable. Conversely, if the result is a small level of association, then the instrument on that variable is not reliable. The results of the translation of the reliability level of the instrument using SPSS 25 are shown in Table 3 below. 
Table 3. Reliability Test

\begin{tabular}{ccc}
\hline Cronbach's Alpha & $\begin{array}{c}\text { Cronbach's Alpha Based on } \\
\text { Standardized Items }\end{array}$ & N of Items \\
\hline 0,615 & 0,614 & 5 \\
\hline
\end{tabular}

Based on the table above, it can be seen in the Cronbach's Alpha column to determine the reliability of the instrument, which is 0.615 and is in the coefficient interval of $0.60-0.799$ which has a strong relationship level. So, it can be concluded that the instrument used is reliable. Furthermore, to analyze the data, the type of data is quantitative data. The data analysis technique started from the normality test, homogeneity test, and hypothesis testing with the help of the SPSS version 25 program.

\section{Finding and Result}

The data from this research includes data on student achievement in each class, namely the experimental class that applies the Inside-Outside Circle (IOC) learning model and the control class uses the conventional learning model. The data analyzed were obtained from the pretest scores given at the beginning of the lesson and the posttest scores given at the end of the lesson. Before being given the treatment, students did a pretest in the experimental class and the control class. In table 4, the following are the results of the descriptive pretest analysis in the experimental class and control class.

Table 4. Descriptive Statistics Pretest

\begin{tabular}{lccccc}
\hline & N & Minimum & Maximum & Mean & Std. Deviation \\
\hline Experiment & 15 & 35 & 60 & 48,67 & 6,673 \\
Control & 15 & 35 & 65 & 49,33 & 7,287 \\
Valid N (listwise) & 15 & & & & \\
\hline
\end{tabular}

Based on table 4, it shows that the experimental class got the lowest pretest score of 35 and the highest was 60, while the control class got the lowest pretest score of 35 and the highest was 65 . For the pretest average score of the experimental class was 48.67 and the control class was 49.33 . So the results of the pretest scores for the experimental class and the control class were not much different. After that, students are given treatment (learning process). Both classes received the same subject matter, namely theme 7 sub-themes 1 science content. It's just that the use of the learning model is different, for the experimental class using the Inside-Outside Circle (IOC) learning model while the control class uses the conventional learning model. Next, students do a posttest. Posttest aims to answer the formulation of this problem. The results of the descriptive analysis of the posttest experimental class and control class are presented in Table 5 below.

Table 5. Descriptive Statistics Posttest

\begin{tabular}{lccccc}
\hline & N & Minimum & Maximum & Mean & Std. Deviation \\
\hline Experiment & 15 & 65 & 95 & 82,33 & 11,629 \\
Control & 15 & 60 & 85 & 70,33 & 7,898 \\
Valid N (listwise) & 15 & & & & \\
\hline
\end{tabular}

Based on table 12, it is found that the experimental class gets the lowest posttest score of 65 and the highest is 95, while the control class gets the lowest posttest score of 60 and the highest is 85 . For the average posttest score of the experimental class is 82.33 and the control class is 70.33. The posttest data from the experimental class and control class students will be the data used in the hypothesis test and will answer the problem formulation in this study. Furthermore, to answer the problem formulation of this study, the normality test, homogeneity test, and hypothesis test were carried out using the SPSS 25 application. The normality test aims to determine whether the learning outcome data is normally distributed or not. This normality test uses the Kolmogorov-Smirnov test in SPSS 25 provided that if sig $<0.05$ then the data does not spread normally and if sig $>0.05$ then the data spread normally. The posttest results of student learning in the experimental class and control class are described in table 6 below. 
Table 6. Test of Normality

\begin{tabular}{cccc}
\hline \multirow{2}{*}{ Class } & \multicolumn{3}{c}{ Kolmogorov-Smirnov $^{\mathbf{a}}$} \\
\cline { 2 - 4 } & Statistic & Df & Sig. \\
\hline Exsperiment (IOC) & 0,195 & 15 & 0,128 \\
Control (Konvensional) & 0,150 & 15 & 0,200 \\
\hline
\end{tabular}

Based on table 6, for Kolmogorov-Smirnov, the experimental class used the sig $=0.128$ and the control class used the sig $=0.200$ level. The normality test on the posttest results of the experimental class is sig $>0.05(0.128>0.05)$ and the posttest results for the control class are sig> $0.05(0.200>0.05)$, this indicates that the two data are normally distributed. If the two data are normally distributed, then the homogeneity test is carried out. The homogeneity test is used to determine whether the measuring scale has the same value or not. In this study the homogeneity test used one-way ANOVA (Anova One Way) in SPSS version 25 . With the provisions, if the sig value $>0.05$ then $\mathrm{H0}$ is accepted or the data variance is homogeneous and if the sig value $<0.05$ then $\mathrm{H} 0$ is rejected or the data variance inhomogeneous. The results of the homogeneity test on the posttest data of the experimental class and control class are described in table 7 below.

Table 7. Test of Homogeneity of Variance

\begin{tabular}{|c|c|c|c|c|c|}
\hline & & $\begin{array}{c}\text { Levene } \\
\text { Statistic }\end{array}$ & $d f 1$ & $d f 2$ & Sig. \\
\hline STUDENTS' LEARNING & Based on Mean & 2,465 & 1 & 28 & 0,128 \\
\hline \multirow[t]{3}{*}{ OUTCOMES } & Based on Median & 1,586 & 1 & 28 & 0,218 \\
\hline & $\begin{array}{l}\text { Based on Median and with } \\
\text { adjusted df }\end{array}$ & 1,586 & 1 & 26,184 & 0,219 \\
\hline & Based on trimmed mean & 2,361 & 1 & 28 & 0,136 \\
\hline
\end{tabular}

Based on table 7 above, the mean of the learning outcome data shows the value of 2.465 , while the Median $=1.586$. Because the significance value (Sig) Based on Mean is 0.128, so sig 0.128>0.05, which means it can be concluded that the variance of the posttest group in the experimental class and the posttest control class is the same or homogeneous. If the data is homogeneous, then test the hypothesis. This hypothesis test uses the independent sample test formula on SPSS 25. Based on decision making, if sig $<0.05$ then there is a significant difference between the posttest results of the experimental and control classes, and if sig $>0.05$ then there is no significant difference between the results. posttest experimental and control classes. Table 8 below describes the results of hypothesis testing in the SPSS 25 application.

Table 8. Independent Sample Test

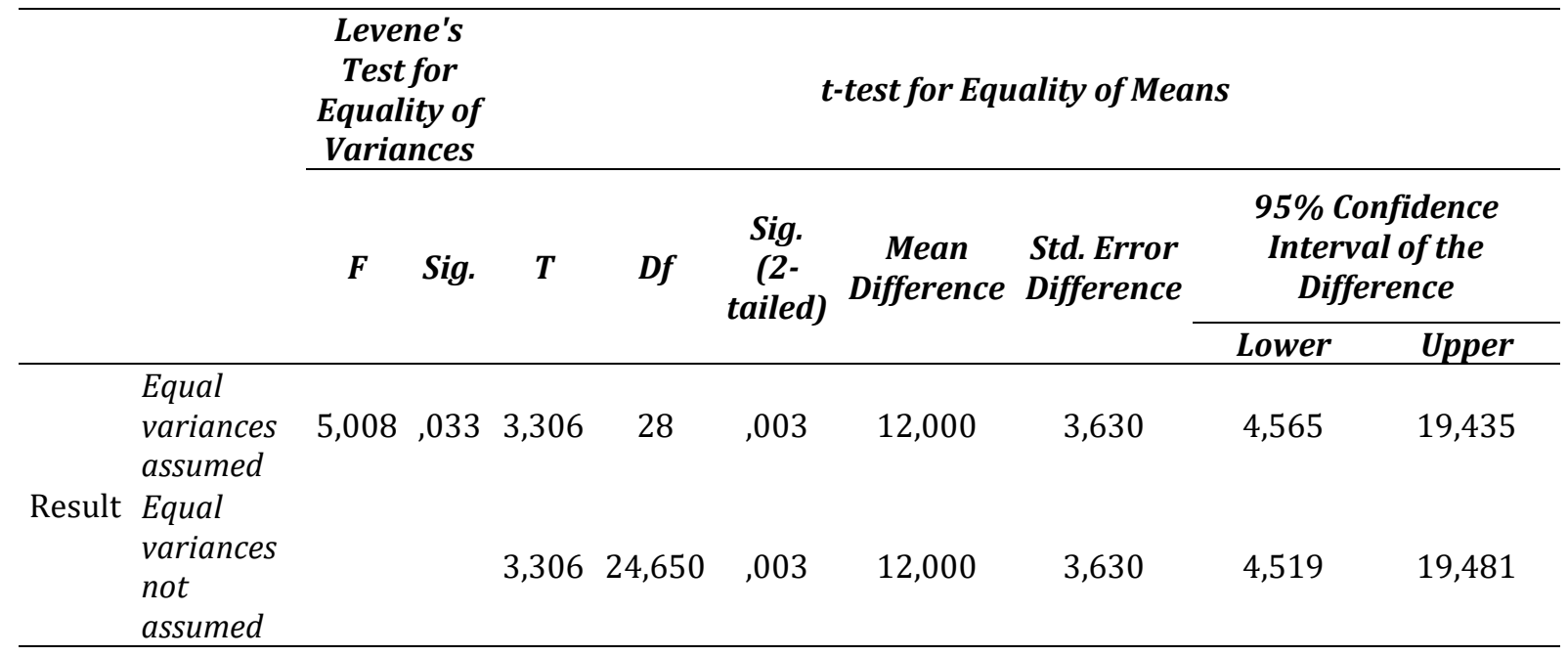

Based on table 8 , there is a significant value of 0.003 so that sig $<0.05(0.003<0.05)$, which means that there is a significant effect, then $\mathrm{HO}$ is rejected. For the t-count obtained is 3.306 with $\mathrm{df}=28$ and a 
significant level of 0.05 , the $t$-table is 2.04841 . $\mathrm{H} 0$ is rejected if $t$-count $\geq t$-table $(3.306 \geq 2.04841)$ then Ha is accepted. In table 9 below, it can be seen the difference in posttest scores between the experimental class and the control class.

Table 9. Group Statistics

\begin{tabular}{lccccc}
\hline & Class & N & Mean & Std. Deviation & Std. Error Mean \\
\hline \multirow{2}{*}{ Result } & Experiment & 15 & 82,33 & 11,629 & 3,003 \\
& Control & 15 & 70,33 & 7,898 & 2,039 \\
\hline
\end{tabular}

Based on table 9, the average value for the experimental class is 82.33 and the average value for the control class is 70.33. So that the Inside-Outside Circle (IOC) learning model has a positive effect on the learning achievement of fourth-grade students of SDN Kersagalih on theme 7 sub-themes 1 on science content. This research begins with conducting a pretest in the experimental class and the control class. From the test results, it was found that the experimental class got the lowest pretest score of 35 and the highest was 60, while the control class got the lowest pretest score of 35 and the highest was 65 . For the pretest average score of the experimental class was 48.67 and the control class was 49.33 . So, the results of the pretest scores for the experimental class and the control class were not much different. Furthermore, the treatment was carried out in three meetings in the learning process for the experimental class and the control class. The learning process in the experimental class uses the Inside-Outside Circle (IOC) learning model, while the control class uses a conventional learning model. After being given the treatment, the experimental class and control class students did a posttest. Based on the results obtained by using a hypothesis test in the form of an independent sample test, the sig value is $0.003<0.05$, which means that there is a significant effect. HO is rejected and Ha is accepted so that the Inside-Outside Circle (IOC) learning model has a significant effect on the learning achievement of fourth-grade students of SDN Kersagalih on theme 7, sub-theme 1, IPA content. For t-count that is obtained is 3.306 and table is 2.04841. The t-count obtained is in a positive region or 3.306>2.04841 so that Ha is accepted. After being given the treatment, the average value of the experimental class became 82.33 and the control class was $70.33(82.33>70.33)$ so that it can be concluded that the Inside-Outside Circle learning model has a significant effect on the learning process.

Based on the research results it can be stated that the IOC model has a positive effect on the catch up process. This is because the Inside-Outside Circle (IOC) learning model or inner-outer circle is a cooperative learning model, specially designed in a curve so that students are allowed to express their communication skills. Inside the outside circle is a learning model with a system of small circles and large circles that begins with the formation of large groups in the classroom consisting of inner circle groups and outer circle groups (Shoimin, 2014; Qusyairi, 2018). The purpose of this inside-outside circle learning technique is that students can get various information at the same time (simultaneously). This technique provides opportunities for students to hone their communication skills, students have the opportunity to process information, this technique also has the potential to activate children who are considered passive to become active. This statement is supported by, (Nuraeni, 2017) found that Inside-Outside Circle (IOC) learning can optimize student learning activities. (Muyaroah, 2018) also found that there is the effectiveness of learning outcomes carried out using the Inside-Outside Circle model in science subjects compared to conventional learning models. This is evidenced in the control class the average learning outcomes reached 72.69 while the experimental class reached 84.06. Whereas in the effectiveness test, the $t$-count value of 5.672 and the $t$-table value for $n$ of 30 reached 1.703 .

Learning with the Inside-Outside Circle (IOC) model makes students more excited and more motivated to learn. This is because in the learning process students are directly involved in actively participating in learning activities. In the early stages of learning the teacher divides students into groups of 3-4 people; Each group gets the task of finding information based on the division of tasks from the teacher; Each self-study group, looking for information based on the assigned assignment After finishing, all students gather to mingle (not based on groups); half of the class then stood in a small circle facing out; the other half of the class form. The circle outside the first circle, facing inward; two pairs of students from small and large circles share information. Students are allowed to directly communicate with other friends and ask questions related to the ongoing science learning. This information exchange can be done by all couples at the same time; then the students in the small circle stay put, while the students who are in the big circle move one or two steps clockwise; now turn for students to be in the big circle of information sharing. And so on, until all students have finished sharing information; The movement will only be stopped when members of the inner and outer circle groups as the original couple meet again. This 
process is in line with the opinion of (Sudaryono, 2016) which states that to achieve maximum learning outcomes, there must be five main elements applied, namely positive interdependence, individual responsibility, promotive interaction, communication between students, and group processes.

Learning carried out in research with the Inside-Outside Circle (IOC) model is student-centered, students are not objecting but research subjects. This is done to build students' attention and concentration. Students are actively involved in the learning process, build student motivation to learn, and communicate what things they understand and what they want to ask directly with their partner friends. Meanwhile, in this case, the teacher functions as a facilitator in providing an understanding of learning material in particular and overall learning in general (Azhary, 2013). The advantages are given to the implementation of this learning model also have a major influence on changes in student achievement and learning outcomes. In applying this IOC model, students can get different information at the same time, more ideas that students can come up with when interacting directly with their friends, able to influence student motivation and activeness, help increase students' self-confidence, help assess their abilities, invites students to be able to act so that students do not tend to be passive, triggers students to want to think and speak skillfully (Azmi, 2015). With student involvement in learning more optimally, it causes learning to take place more effectively. In the end, this learning model can improve student learning achievement (Qusyairi, 2018).

This research is also supported by research conducted by (Haryati, 2016), namely the application of the Cooperative Learning Type Inside-Outside Circle Model conducted at SDN Karangjambe in social studies subjects which can improve student learning outcomes in both cognitive, affective and psychomotor aspects of students. Especially in the cognitive aspect, in the first cycle, only 13 out of 25 students (52\%) of students reached the KKM. The second cycle increased to 16 students (64\%) students who reached the KKM. The third cycle of students who reached the KKM reached 23 students (92\%). Whereas in the affective aspect, in the first cycle with good criteria in the aspect of cooperation there were 14 students, 12 students in disciplinary aspects, and 11 students in responsibility aspects. In the second cycle with good criteria in the aspects of cooperation 17 students, aspects of discipline 15 students, and aspects of responsibility 14 students. In the third cycle with good criteria in the aspects of cooperation of 24 students, disciplinary aspects of 23 students, and aspects of responsibility of 22 students. In the psychomotor aspect, the assessment includes the suitability of the question cards with the material, the suitability of the questions with the answers, and the independence of students in doing assignments. In the first cycle of aspects, the suitability of the question cards with the material was only 12 students, the suitability of the questions with the answers of 15 students, and the independence of students in doing 17 students' assignments.

The second cycle on the aspect of the suitability of the question cards with the material only 18 students, the suitability of the questions with the answers of 19 students, and the independence of students in doing the assignments of 23 students. The third cycle on the aspect of the suitability of the question cards with the material is only 23 students, the suitability of the questions with the answers of 21 students, and the independence of students in doing the assignments of 24 students. Trisna Susanti (2017) on the Effect of an Environment-Based Inside Outside Circle Learning Model on Science Learning Outcomes of Class V Elementary School Students. He found that there were significant differences in science learning outcomes between students who were applied with the Inside-Outside Circle model and students who were taught using the conventional model. This can be seen from the average science learning outcomes of the group of students who are taught with the IOC 80.86 learning model (in the very high category), while the average score of student group science learning outcomes taught with conventional learning models is 48 (in the category moderate). The result of the t-test calculation shows that $\mathrm{t}$ count $=7.52$ and $\mathrm{t}$ table with $\mathrm{dk}=56$ at the significance level of $5 \%=2,000$. This indicates that the application of the Inside Outside Circle (IOC) learning model can improve student learning outcomes. Based on the explanation above, it can be concluded that this research provides new findings that can help in the learning process so that learning can be interesting and make students not quickly bored without deviating from the goals to be achieved. So that the implications of the research can later be used as a reference and can be used to teach any material in the classroom using the Inside-Outside Circle learning model.

\section{Conclusion}

Based on the results of the data analysis that has been studied, it can be concluded that learning with the Inside-Outside Circle (IOC) learning model has a significant effect on student achievement on theme 7 sub-theme 1 science content in grade IV SDN Kersagalih. Based on the average value of the experimental class $>$ the mean value of the control class $(82.33>70.33)$, the Inside-Outside Circle (IOC) 
learning model has a positive influence on the learning achievement of fourth-grade students of SDN Kersagalih on theme 7, sub-theme 1 content IPA.

\section{Reference}

Angganing, P. (2019). Penggunaan Metode Inside Outside Circle untuk Meningkatkan Hasil Belajar IPS. Dwija Cendekia: Jurnal Riset Pedagogik, 3(1), 23-29. https://doi.org/10.20961/jdc.v3i1.31438

Apriani, Nuning, dkk. (2016). Pengaruh Model Pembelajaran Berbasis Masalah Terhadap Hasil Belajar Fisika Siswa Kelas X SMAN 2 Praya Tahun Pelajaran 2015/2016. Jurnal Pijar MIPA, 11(2), 125-130. http://dx.doi.org/10.29303/jpm.v11i2.114

Arista, Shelly Afrilia, dkk. (2017). Penerapan Model Pembelajaran Inkuiri Untuk Meningkatkan Keterampilan Proses Sains Siswa Kelas VIII.1. Diklabio: Jurnal Pendidikan Dan Pembelajaran Biologi, 1(1), 103-108. https://doi.org/10.33369/diklabio.1.1.100-104

Ariyanto, M. (2016). Peningkatan Hasil Belajar IPA Materi Kenampakan Rupa Bumi Menggunakan Model Scramble. Profesi Pendidikan Dasar, 3(2), 2503-3530. https://doi.org/10.23917/ppd.v3i2.3844

Azhary, M. A. Y. A. (2013). Penerapan Pembelajaran Kooperatif Model Inside Outside Circle Untuk Meningkatkan Hasil Belajar Apresiasi Dongeng Siswa Kelas VIIC MTSN Juwet Ngronggot Nganjuk. JPBSI Online, 1(1), 66-74.

Azmi Nurul. (2015). Model Pembelajaran Inside Outside Circle (IOC) Untuk Meningkatkan Hasil Belajar Siswa Dalam Proses Pembelajaran. Al Ibtida: Jurnal Pendidikan Guru MI, 2(1), 102-111. http://dx.doi.org/10.24235/al.ibtida.snj.v2i1.180

Barsihanor. (2016). Pengaruh Model Pembelajaran Cooperative Learning Teknik Inside Outside Circle terhadap Hasil Belajar Siswa Bidang Studi IPS MI Darul Mujahidin. Jurnal Madrasah Ibtidaiyah, 1(2), 20-30. http://dx.doi.org/10.31602/muallimuna.v1i2.382

Budiartini, N., M. (2018). Pengaruh Model Pembelajaran Inside Outside Circle Berbantuan Asesmen Portofolio Terhadap Hasil Belajar IPA. Jurnal Pedagogik Dan Pembelajaran, 1(2). http://dx.doi.org/10.23887/jp2.v1i2.19337

Fatimah, S. \& I. K. (2013). Pembelajaran IPA Sekolah Dasar Berbasis Pendidikan Karakter. Jurnal AlBidayah, 5(2), 381-297. https://doi.org/10.14421/al-bidayah.v5i2.125

Fatinah. (2017). Meningkatkan Hasil Belajar Siswa Dalam Pembelajaran IPA Dengan Metode Demonstrasi Dikelas V SDN 10 Biau. Jurnal Kreatif Tadulako Online, 5(4), 85-96.

Haryati, Y. D. (2016). Aktivitas Belajar Dalam Pembelajaran Inside-Outside Circle Melalui Lesson Study Pada Kelas V SD. Jurnal Cakrawala Pendas, 2(2), 94-104.

Hendawati, Yuyu, dkk. (2018). Penerapan Model Mind Mapping untuk Meningkatkan Penguasaan Konsep IPA di SD. Metodik Didaktik, 13(2), 113-124. https://doi.org/10.17509/md.v13i2.9498

Mulyasa, E. (2011). Kurikulum Tingkat Satuan Pendidikan. Remaja Rosdakarya.

Muyaroah, S. (2018). Efektifitas Model Pembelajaran Inside Outside Cirle Terhadap Hasil Belajar Siswa Pada Mata Pelajaran IPA SD Fransiskus Baturaja. Jurnal Ilmu Pendidikan, 16(2), 99-104. https://doi.org/10.17509/pdgia.v16i2.12052

Nidawati. (2013). Belajar Dalam Perspektif Psikologi Dan Agama. Jurnal Pionir, 1(1), 13-28. http://dx.doi.org/10.22373/pjp.v4i1.153

Ningsih, S. Y. (2017). Penerapan Model Pembelajaran Inside Outside Circle Terhadap Kemampuan Pemahaman Konsep Siswa. Journal of Mathematics Education and Science, 2(2), 88-94. https://doi.org/10.30743/mes.v2i2.136

Nuraeni, Dwi, dkk. (2017). Aktivitas Belajar Dalam Pembelajaran Inside-Outside Circle Melalui Lesson Study Pada Kelas V SD. Jurnal Pendidikan: Teori Penelitian, Dan Pengembangan, 2(9), 1175-1181. http://dx.doi.org/10.17977/jptpp.v2i9.9931

Purnamawanti. R., Hartati, S., \& S. S. (2015). Pengaruh Model Pembelajaran Kooperatif Tipe Inside Outside Circle Terhadap Kemampuan Berkomunikasi Siswa Pada Materi Organisasi Kehidupan. Jurnal $\begin{array}{llll}\text { Program Studi Pendidikan } & \text { Biologi, 2338-7173. }\end{array}$ 
https://journal.uinsgd.ac.id/index.php/bioeduin/article/download/2459/1641

Qusyairi,Lalu A. Hery, J. S. (2018). Pengaruh Model Cooperative Learning Tipe Inside-Outside Circle (Ioc) Terhadap Prestasi Belajar dengan Memperhatikan Minat Belajar Matematika. Palapa: Jurnal Studi Keislaman Dan Ilmu Pendidikan, 6(1), 34-49. https://doi.org/10.36088/palapa.v6i1.57

Sariadi, Ni Ketut, dkk. (2014). Penerapan Model Pembelajaran Berbasis Masalah Untuk Meningkatkan Hasil Belajar IPA Kelas V SD. E-Journal Mimbar PGSD Universitas Pendidikan Ganesha, 2(1). http://dx.doi.org/10.23887/jjpgsd.v2i1.2562

Saryono, Edi, dkk. (2016). Penerapan Metode Pembelajaran Inside Outside Circle Untuk Meningkatkan Aktivitas Belajar Dan Hasil Belajar Kognitif Siswa Pada Materi Keseimbangan Ekosistem. Jurnal Pendidikan Biologi, 1(1), 40-50. https://doi.org/10.31932/jpbio.v1i1.241

Shoimin, A. (2014). 68 Model Pembelajaran Inovatif dalam Kurikulum 2013. Ar-Ruzz Media.

Suadi, \& Lipur, A. (2019). Peningkatan Prestasi Belajar Ipa Materi Sistem Gerak Pada Manusia Melalui Pembelajaran Cooperative Scrip Pada Siswa Kelas VIII E SMP Negeri 10 Madiun Tahun Pelajaran 2018/2019. Jurnal Ilmia Pengembangan Pendidikan, 4(1), 35-41. https://ejurnalkotamadiun.org/index.php/JIPP/article/view/260

Sudaryono. (2016). Metode Penelitian Pendidikan. Kencana Prenada Media Group.

Sudjana, N. (2010). Dasar-dasar Proses Belajar Mengajar. Sinar Baru Algensindo.

Sugiyono. (2013). Metode Penelitian Pendidikan. Alfabeta.

Sugiyono. (2016). Metode Penelitian Pendidikan. Alfabeta.

Sugiyono. (2019). Metode Penelitian Pendidikan. Alfabeta.

Sukmadinata, N. S. (2016). Metode Penelitian Pendidikan. Remaja Rosdakarya.

Syafi'i, Ahmad, dkk. (2018). Studi Tentang Prestasi Belajar Siswa Dalam Berbagai Aspek Dan Faktor Yang Mempengaruhi. Jurnal Komunikasi Pendidikan, 2(2), 115-123. https://doi.org/10.32585/jkp.v2i2.114

Utami, N.M.S. \& Renda, N. . (2019). Pengaruh Model Pembelajaran Inside Outside Circle (IOC) Terhadap Hasil Belajar IPA. Jurnal Ilmiah Pendidikan Profesi Guru, 2(2), 2621-5705. http://dx.doi.org/10.23887/jippg.v2i2.19187

Wiwinda. (2016). Pelaksanaan Model Pembelajaran Inside Dan Outside Circle Terhadap Hasil Belajar Siswa Pada Mata Pelajaran IPA (Studi Di SMP Budi Mulya Kota Bengkulu. Jurnal Penelitian Dan Pengabdian Masyarakat, 5(2), 123-130. http://dx.doi.org/10.1161/mhj.v4i2.155.g142

Yuhastami, Y. (2015). Peningkatan Aktivitas Dan Hasil Belajar Siswa Terhadap Pembelajaran Menggunakan Teknik Inside Outside Circle Pada Materi Koloid. Jurnal Pendidikan Dan Pembelajaran Khatulistiwa, 4(9). https://jurnal.untan.ac.id/index.php/jpdpb/article/view/11193 